\title{
Pantanodontidae (Teleostei, Cyprinodontiformes), the sister group to all other cyprinodontoid killifishes as inferred by molecular data
}

\author{
Pedro H.N. Bragança ${ }^{1}$, Pedro F. Amorim ${ }^{1}$, \\ Wilson J.E.M. Costa ${ }^{1}$ \\ 21941-971, Rio de Janeiro, Brazil \\ http://zoobank.org/6F1FBCDE-4F58-48FD-9CE9-645DF8A8E181 \\ Corresponding author: Pedro H.N. Bragança (pedrobra88@gmail.com)
}

1 Laboratory of Systematics and Evolution of Teleost Fishes, Institute of Biology, Federal University of Rio de Janeiro, Caixa Postal 68049, CEP

\begin{abstract}
Received 9 November 2017

Accepted 24 January 2018

Published 9 February 2018

Academic editor:

Peter Bartsch

\section{Key Words}

Phylogeny

Molecular Systematics

Classification

Fluviphylacidae

Poeciliidae

Procatopodidae

Pantanodon, containing two African extant species and four European fossil species, for a long time had an uncertain position among the Cyprinodontiformes due to its peculiar morphology. In the last decades, Pantanodon has been considered closely related to African lamp-eyes of the Procatopodinae clade, which is contained in the Poeciliidae, a teleost fish family with a broad geographical distribution in Africa and the Americas. However, recent molecular studies have challenged the monophyly of the Poeciliidae, but the position of Pantanodon remained uncertain. We analysed one mitochondrial (COI) and five nuclear loci (GLYT1, MYH6, SH3PX3, RAG1, ENC1), a total of 5,083 bp, for 27 cyprinodontiform taxa and 6 outgroups, obtaining a well-supported phylogeny, in which the monophyly of Poeciliidae, as supported by morphological data is refuted. Pantanodon stuhlmanni, the type species of the genus, is recovered as the most basal cyprinodontoid lineage and other African taxa formerly placed in Poeciliidae are highly supported as more closely related to European non-poeciliid cyprinodontoid genera than to other taxa. Since the present tree topology is not compatible with the present classification of the Cyprinodontoidei, a new classification using available family group names is provided: Pantanodontidae is used for Pantanodon; Procatopodidae, for the African lamp-eye clade; and Fluviphylacidae, for the South American genus Fluviphylax. Poeciliidae is restricted to the American livebearers, hence restoring the classification generally used prior to 1981 .
\end{abstract}

\section{Introduction}

The teleost order Cyprinodontiformes is a diverse group of small fishes living in freshwater and estuarine environments of all continents, except Oceania and Antarctica. Many of them are popular aquarium fishes, but some species such as guppies and mangrove killifishes are among the most important experimental species used as model organisms for a large spectrum of scientific areas. However, cyprinodontiform classification is still not well established despite continuous efforts to understanding their phylogenetic relationships (e.g. Rosen 1964, Parenti 1981, Costa 1998, Pollux et al. 2014, Pohl et al. 2015).
Prior to Parenti's (1981) phylogenetic analysis, cyprinodontiform classifications were mainly based on sexually dimorphic characters to delimit groups, focusing on the presence and morphology of copulatory organs in males and viviparity (e.g., Garman 1895, Regan 1911). After Hubbs (1924), cyprinodontiforms were often classified in four families of internally fertilizing viviparous taxa: the Anablepidae, Jenynsiidae, Goodeidae, and Poeciliidae, and one diverse oviparous family, the Cyprinodontidae, which was subsequently divided in several subfamilies (e.g. Myers 1931, 1955). Among cyprinodontid subfamilies, Pantanodontinae contained a single genus, Pantanodon Myers, 1955, a peculiar group of small spe- 
cies with a series of unique osteological features, amongst others, jaw and branchial arch morphology (Whitehead 1962, Rosen 1965). Until 1981, these unique morphological traits found in Pantanodon intrigued ichthyologists who did provide complete osteological reviews (Whitehead 1962, Rosen 1965), but still refrained from positioning the genus among other Cyprinodontiformes, and even suggested to place it in a separate family (Rosen 1965). Pantanodon presently comprises two African extant species (e.g. Rosen 1965, Seegers 1996) and at least four European fossil species (e.g. Costa 2012a).

In the cyprinodontiform classification provided by Parenti (1981) on the basis of her phylogenetic analysis of morphological characters, oviparous taxa previously placed in a single family, Cyprinodontidae, were distributed among nine different families, belonging to two well supported suborders: the Aplocheiloidei, comprising Aplocheilidae and Rivulidae, and the Cyprinodontoidei, comprising Anablepidae, Cyprinodontidae, Fundulidae, Goodeidae, Poeciliidae, Profundulidae, and Valenciidae. The Poeciliidae then became a more inclusive taxon comprising three subfamilies, the American livebearers being grouped in Poeciliinae, the oviparous African lamp-eyes and Pantanodon in Aplocheilichthyinae, and the South American oviparous killifish genus Fluviphylax Whitley, 1965 in Fluviphylacinae. Costa (1996) transferred Fluviphylax to Aplocheilichthyinae, but Ghedotti (2000) subsequently restricted Aplocheilichthyinae to a single genus and species, Aplocheilichthys spilauchen (Duméril, 1861), transferring other oviparous African lamp-eyes, Pantanodon and Fluviphylax to Procatopodinae.

Recently, some molecular phylogenetic analyses (Pollux et al. 2014, Pohl et al. 2015, Reznick et al. 2017) challenged the monophyly of Poeciliidae sensu Parenti (1981). These studies indicated the African Procatopodinae as the sister group of a clade comprising European non-Poeciliidae cyprinodontoid genera (Valencia Myers, 1928 and Aphanius Nardo, 1827). In addition, Pollux et al. (2014) and Reznick et al. (2017) based on a broad sample of New World cyprinodontoid taxa supported the South American Fluviphylax as the sister group of a Neotropical clade comprising Poeciliinae and Anablepidae, but did not include Pantanodon in their analyses. A species of the latter genus, Pantanodon stuhlmanni (Ahl, 1924) was tentatively included in a phylogenetic analysis (Pohl et al. 2015), based on two mitochondrial and three nuclear genes. However, the phylogenetic position of P. stuhlmanni was not well supported, possibly as a consequence of incomplete data sample. The analysis of the complete concatenated dataset indicated P. stuhlmanni as the sister group of a clade comprising all other cyprinodontoids, but this placement was poorly supported. On the other hand, in all single gene trees, P. stuhlmanni appeared outside the cypridontiform clade, but again without relevant support. Pohl et al. (2015) then concluded that the phylogenetic position of Pantanodon remained largely unresolved.
In order of to test the phylogenetic position of Pantanodon and search for a more stable classification, the present study includes a larger gene sample, comprising one mitochondrial and five nuclear genes for representatives of all cyprinodontiform families. A comparative analysis of extant and fossil species of Pantanodon provides an updated diagnosis for the genus.

\section{Material and methods}

\section{Taxon sampling}

Twenty species of Cyprinodontoidei, representing all the main lineages as previously described in morphological (Parenti 1981, Costa 1998, Ghedotti 2000) and molecular studies (Pollux et al. 2014, Pohl et al. 2015), were analysed in this study, in addition to seven species of Aplocheiloidei. Since Pantanodon includes only two nominal extant species, $P$. stuhlmanni, the type species, and P. madagascariensis (Arnoult, 1963), and the latter has not been collected since the 1960's and is presently considered as extinct (Sparks 2016), only the former species was included in the analysis. Outgroups comprised three representatives of Beloniformes, Oryzias latipes (Temminck \& Schlege, 1846), Cheilopogon melanurus (Valenciennes, 1847), and Xenentodon cancila (Hamilton, 1822); two of Atheriniformes, Labidesthes sicculus (Cope, 1865) and Menidia beryllina (Cope, 1867); and one Cichlidae, Heterochromis multidens (Pellegrin, 1900). The latter was used to root the phylogenetic trees, following hypotheses of Ovalentaria relationships, wherein Cichlomorphae is supported as the sister group of Atherinomorphae (Wainwright et al. 2012; Betancur-R et al. 2013). All sequenced specimens used in this study are deposited in the Institute of Biology, Federal University of Rio de Janeiro, Rio de Janeiro (UFRJ) and the Royal Museum for Central Africa, Tervuren (MRAC). In order to avoid large sets of missing data, in three cases when COI sequences were not available for the selected terminal taxa, we used sequences available in GenBank for closely related species: Aplocheilus panchax (KU.692279.1) was included as data for A. lineatus; Aphanius anatoliae (KJ.552353.1), for A. isfahanensis; and Poeciliopsis occidentalis (HQ.556956.1), for P. elongata. A list of species and the respective GenBank accession numbers appear in Supplementary material 1. The material examined for checking morphological diagnostic features of Pantanodontidae is deposited in the following institutions: Institute of Biology, Federal University of Rio de Janeiro, Rio de Janeiro (UFRJ), Royal Museum for Central Africa, Tervuren (MRAC), Museum für Naturkunde, Berlin (MB.f, Palaeontology; ZMB, Ichthyology), Muséum national d'Histoire naturelle, Paris (MNHN.P, Palaeontology; MNHN, Ichthyology) Museum of Zoology, University of Michigan, Ann Arbor (UMMZ), Národní Muzeum, Prague (NMP), and Natural History Museum, London (NHMUK(P), Palaeontology; BMNH, Ichthyology); all material is listed in Supplementary material 2. 


\section{Osteological preparations and nomenclature}

Osteological studies were made on cleared and stained specimens (c\&s) prepared according to Taylor and Van Dyke (1985) and nomenclature for bone structures follows Costa (2006).

\section{DNA sequencing}

The genomic DNA was extract from muscle tissue of the right side of the caudal peduncle using DNeasy Blood \& Tissue Kit (Qiagen) according to the manufacturer instructions. To amplify the fragments of DNA were used the primers Glyt_F559 and Glyt_R1562, for the Glycosyltransferase gene (GLYT1), myh6_F507 and myh6_R1325, for the cardiac protein encoding gene, Myosin heavy chain 6 (MYH6), SH3PX3_F461, SH3PX3 R1303, SH3PX3 F532 and SH3PX3 R1299, for the $\overline{\mathrm{SH}} 3$ and PX domain-containing 3-like protein (SH3PX3) (Li et al. 2007), RAG1F1, RAG1R2 (Lopez et al. 2004) and H3405 (Hrbek et al. 2007) for the recombination activation gene 1 (RAG1), ENC1_F88, ENC1_F85, ENC1_R975, ENC1_R982 (Li et al. 2007) and the primers ENC1_FPAN (5'-ATGCTGYTWCTGTCTGAYGCCCACCAGTG-3'), ENC1_RPAN (5'GCYTTBGGRATKATCTCTTTGGC -3') herein developed for the ectodermal neural cortex 1 gene, LCO1490, HCO2198 (Folmer et al. 1994) for the Cytochrome c oxidase subunit I (COI), 16sar-L and 16sbr-H (Palumbi et al. 1991) for the 16S ribosomal RNA gene. The annealing temperatures for the primers ENC1_FPAN and ENC1_RPAN is $59^{\circ} \mathrm{C}$. Polymerase chain reactions (PCR) were performed in $30 \mu \mathrm{l}$ reaction mixtures containing $5 \times$ Green GoTaq Reaction Buffer (Promega), 3.6 $\mathrm{mM} \mathrm{MgCl} 2,1 \mu \mathrm{M}$ of each primer, $50 \mathrm{ng}$ of total genomic DNA, $0.2 \mathrm{mM}$ of each dNTP and $1 \mathrm{U}$ of Taq polymerase. The thermocycling profile was: (1) 1 cycle of 4 minutes at $94{ }^{\circ} \mathrm{C}$; (2) 35 cycles of 1 minute at $92{ }^{\circ} \mathrm{C}, 1$ minute at $49-60{ }^{\circ} \mathrm{C}$ (varying according to the primer and the sample) and 1 minute at $72{ }^{\circ} \mathrm{C}$; and (3) 1 cycle of 4 minutes at $72{ }^{\circ} \mathrm{C}$. In all PCR reactions, negative controls without DNA were used to check contaminations. Amplified PCR products were purified using the Wizard SV Gel and PCR Clean-Up System (Promega). Sequencing reactions were made using the BigDye Terminator Cycle Sequencing Mix (Applied Biosystems). Cycle sequencing reactions were performed in $10 \mu \mathrm{l}$ reaction volumes containing $1 \mu \mathrm{l}$ BigDye 2.5X, $1.55 \mu \mathrm{l}$ sequencing buffer $5 \mathrm{X}$ (Applied Biosystems), $2 \mu \mathrm{l}$ of the amplified products (10 - 40 ng), and $2 \mu \mathrm{l}$ primer. The thermocycling profile was: (1) 35 cycles of 10 seconds at $96{ }^{\circ} \mathrm{C}, 5$ seconds at $54{ }^{\circ} \mathrm{C}$ and 4 minutes at $60{ }^{\circ} \mathrm{C}$. The sequencing reactions were purified and denatured and the samples were run on an ABI 3130 Genetic Analyzer. Sequences were edited using MEGA 6 (Tamura et al. 2013) and aligned using ClustalW (Chenna et al. 2003). The DNA sequences were translated into amino acids residues to test for the absence of premature stop codons or indels using the program MEGA 6.0.

\section{Gene sampling}

For each gene and codon position Measure Substitution Saturation tests were performed according to the model proposed by Xia et al. (2003), considering only fully resolved sites in DAMBE5 (Xia 2013). Preliminary trees were executed for partitions with high saturation level, and the tree topology (symmetrical/asymmetrical) were considered when evaluating the Iss and Iss.c values. The third position of COI and the $16 \mathrm{~S}$ gene showed substantial saturation as well as the third position of ENC1 nuclear gene and they were then removed from the analysis. The concatenated dataset included the following genes: GLYT, MYH6, RAG1, SH3PX3, the first and the second codon position of ENC1 and the first and second codon position of the mitochondrial gene COI comprising 5,083 bp. A preliminary phylogenetic analysis was performed including the $16 \mathrm{~S}$ to the concatenated dataset and its inclusion dropped the bootstrap supports and posterior probability values of both shallow and deep nodes. This analysis is presented in Supplementary material 3.

\section{Phylogenetic analysis}

The dataset was partitioned according to each gene. The best-fit evolutionary model was calculated for each partition using the Akaike Information Criterion (AIC) determined by the jModelTest 2.1.7 (Darriba et al. 2012). The best model for each partition is presented in Supplementary material 4 . To check for major discordance among individual gene trees, maximum likelihood trees were generated for each gene alignment, using MEGA 6 (Tamura et al. 2013). Since separate analyses did not result in conflicting trees, data were concatenated, with the whole dataset containing 5,083 bp. The phylogenetic analyses were conducted through Maximum Likelihood (ML), using the program Garli 2.0 (Zwickl 2006), and Bayesian Inference (BI), using the program MrBayes v3.2.5 (Ronquist et al. 2012). The values of support of the ML analysis were calculated by 1000 bootstrap replications (Felsenstein 1985). BI was conducted using two Markov chain Monte Carlo (MCMC) runs of two chains each for 3 million generations, a sampling frequency of 1000 . The quality of the MCMC chains was evaluated in Tracer 1.6, and a $25 \%$ burn-in was removed.

\section{Results}

The ML analysis (Fig. 1) generated a tree with most clades receiving high bootstrap values (higher than $95 \%$ ), including among them the nodes supporting the Cyprinodontiformes and the Aplocheiloidei. Pantanodon stuhlmanni appeared as the sister group of all other cyprinodontoids (91\%), and the clade including all cyprinodontoids except P. stuhlmanni was also highly supported (100\%). In the BI analysis (Supplementary material 5), almost the same topology was reached, with the above mentioned clades showing high posterior probability values (above $0.95 \%$ ). 


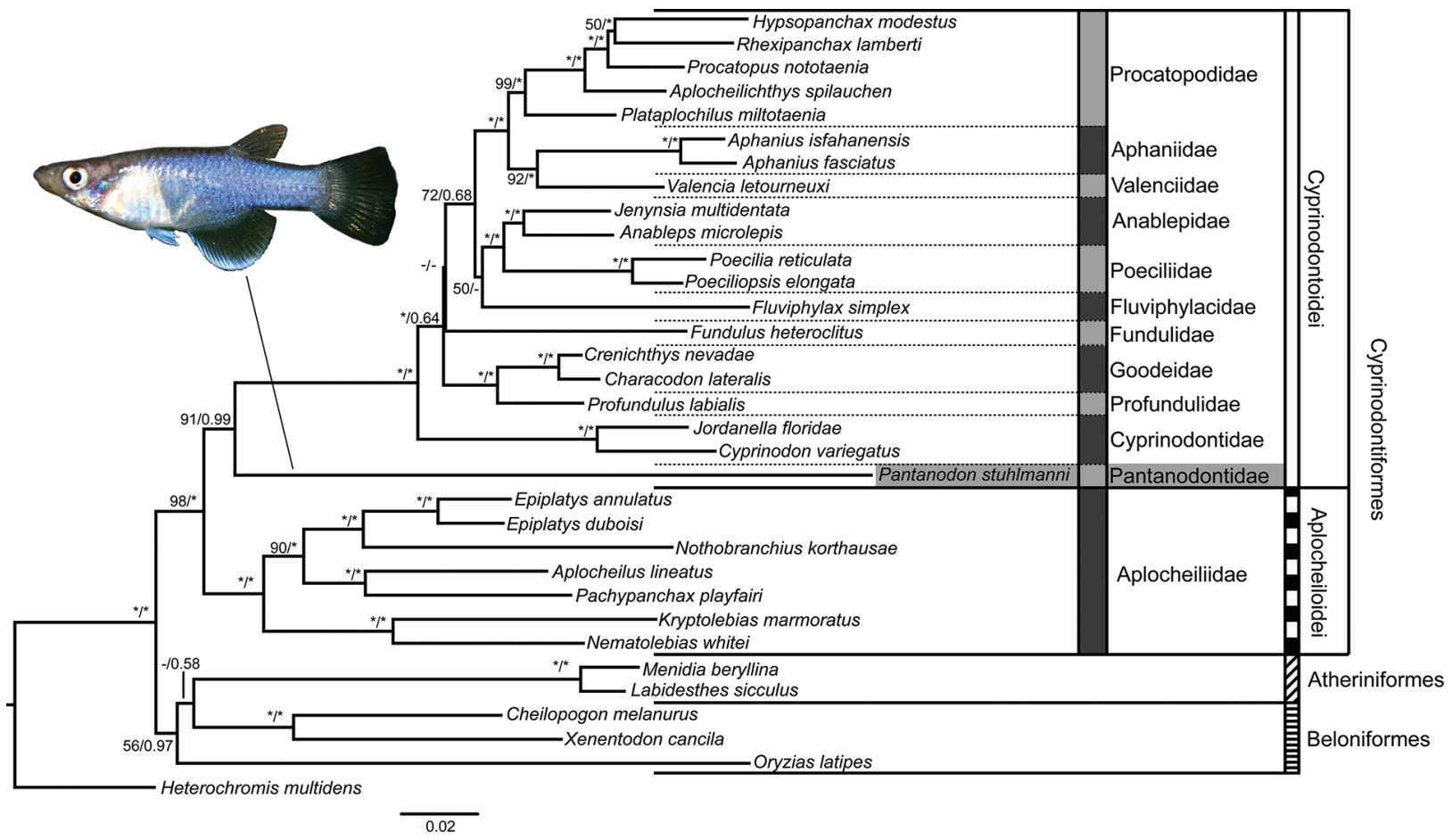

Figure 1. Phylogenetic relationship tree generated by a Maximum Likelihood Analysis of molecular data ( $5,083 \mathrm{bp}$, comprising segments of the nuclear genes ENC1, GLYT, MYH6, SH3PX3 and RAG1 and the mitochondrial gene COI). Clade names follows the classification herein proposed. Numbers on each node are bootstrap percentages of the Maximum Likelihood analysis and posterior probabilities of the Bayesian Inference analysis; asterisks indicate maximum values (100 or 1.00 respectively) and a dash refers to values under 50 or 0.50 respectively.

The main difference occurred in the position of Fluviphylax simplex Costa, 1996 (sister to a clade comprising only the Anablepidae and the Poeciliidae in ML analysis, vs. sister to a clade comprising the Procatopodidae, represented by Aplochilichthys spilauchen, Hypsopanchax modestus, Plataplochilus miltotaenia, Procatopus nototaenia, Rhexipanchax lamberti, Valenciidae, Aphaniidae, Anablepidae, and Poeciliidae in BI analysis), but the relative position of Pantanodon was the same in both analyses (Figure 1, Supplementary material 5).

\section{Discussion}

\section{Phylogenetic position of Pantanodon and African lamp-eyes}

The present analysis is consistent with previous morphological and molecular studies in supporting the monophyly of the Cyprinodontiformes, which contains two well established clades, the suborders Aplocheiloidei and Cyprinodontoidei (Parenti 1981, Costa 1998, Pollux et al. 2014, Pohl et al. 2015). However, monophyly of the Poeciliidae as inferred from morphological data (Parenti 1981, Costa 1998, Ghedotti 2000) is refuted. The poecilines are considered to be sister to the Anablepidae, whereas the Procatopodines are closer to the Old world genera Aphanius and Valencia. Instead of being a taxon belonging to the African lamp-eye clade (= Procatopodinae sensu Ghedotti 2000), Pantanodon stuhlmanni is herein supported as the sister group of a clade encompassing all other cyprinodontoids (Fig. 1), thus considered as a member of a separate family, the Pantanodontidae (see Taxonomic implications below). Species of this family exhibit morphological synapomorphies previously used to diagnose the Cyprinodontoidei (Parenti 1981, Costa 1998, 2012b), corroborating its inclusion in this suborder: (1) dentary expanded medially resulting in a robust lower jaw (Fig. 2A), (2) rostral cartilage absent (Fig. 2A), (3) metapterygoid absent (Fig. 2A), (4) dorsal hypohyal absent (Fig. 3C), (5) first basibranchial absent (Fig. 3E), and (6) distal portion of the neural and haemal spines of the preural vertebrae 3 wider than neural and haemal spines of preural vertebrae 4 (Fig. 2D). However, no morphological character was found to support the clade comprising all cyprinodontoids except Pantanodontidae, probably as a result of the high specialised morphology of Pantanodontidae avoiding clear homology assumptions for several structures.

Our analysis highly supports the monophyly of the group ecompassing all African lamp-eyes species, corroborating previous morphological studies (Parenti 1981, Costa 1996), but refuting Ghedotti's (2000) analysis, who considered African lamp-eyes to form a paraphyletic assemblage. According to that study, the species Aplocheilichthys spilauchen is the sister group of a clade including the remaining African lamp-eyes and the American Poeciliinae, represented herein by Poecilia reticulata and Poeciliopsis elongata. In contrast, the African lamp-eye 

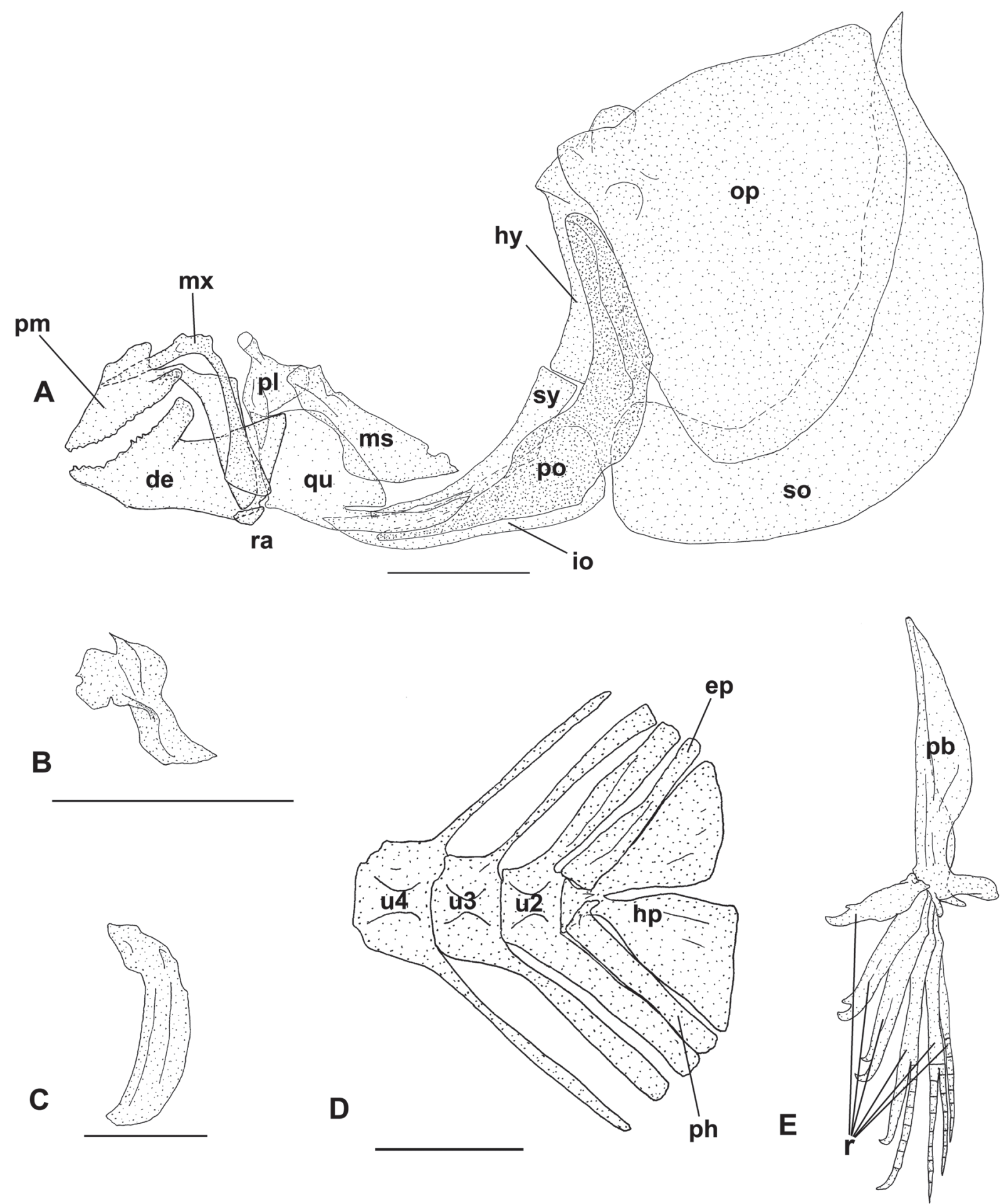

Figure 2. Jaws, jaw suspensorium, opercular apparatus, superficial dermal bones and caudal fin skeleton of Pantanodon stuhlmanni and pelvic fin of $P$. madagascariensis: A: left jaws, jaw suspensorium and opercular apparatus, lateral view; B, left nasal, dorsal view; C, left lachrymal, lateral view; D, caudal fin skeleton, left lateral view; E: pelvic fin bone and rays. Abbreviations: de, dentary; ep, epural; hp, hypural plate; hy, hyomandibula; io, interopercle; ms, mesopterygoid; pb, pelvic bone; ph, parahypural; pl, palatine; pm, premaxila; po, preopercle; qu, quadrate; r, rays; ra, retroarticular; so, subopercle; sy, sympletic; u2-u4, preural centra 2-4. Scale bar $=1 \mathrm{~mm}$. Figure 2E was based on illustration present in Rosen (1965), that originally do not have scale bar.

clade is highly supported as the sister group to a clade comprising the European genera Aphanius and Valencia, whereas the Poeciliinae is considered to be sister to the Anablepidae, both results agreeing with recent molec- ular phylogenies using different samples, terminal taxa and DNA markers (Pollux et al. 2014, Pohl et al. 2015, Reznkick et al. 2017). The present study also refutes the South American Fluviphylax as a member of the African 

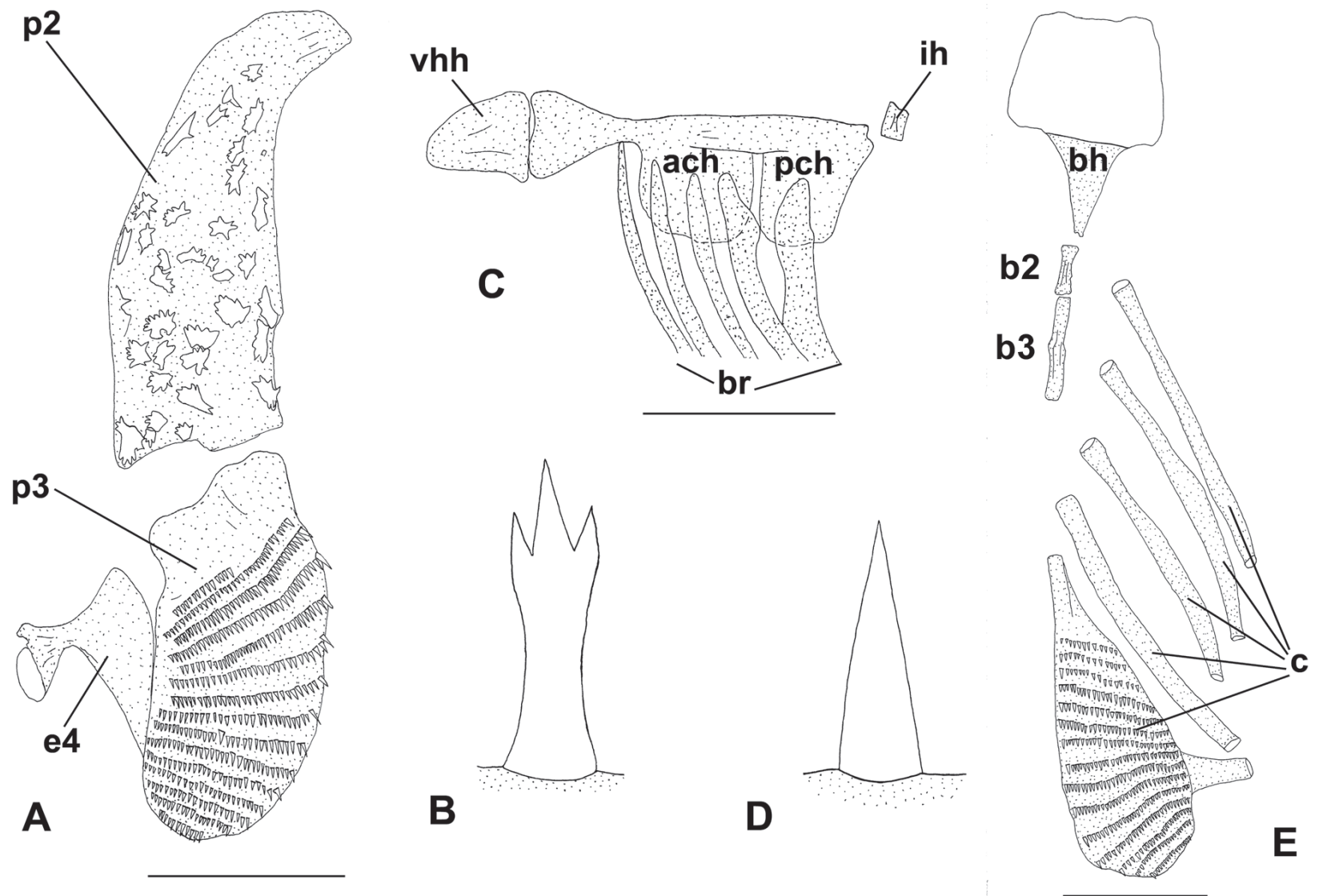

Figure 3. Branchial arches of Pantanodon stuhlmanni: A, left branchial arches, ventral view of dorsal portion; B, third pharyngobranchial tooth, frontal view; C, left hyoid bar, lateral view; D, fifth ceratobranchial tooth, frontal view; E, left and middle branchial arches, dorsal view of ventral portion. Abbreviations: ach, anterior ceratohyal; b1-2, basibranchials 1-2; bh, basihyal; br, branchiostegal rays; c, ceratobranchials; e4,fourth epibranchial; ih, interhyal; p2-3, pharyngobranchials 2 and 3, pch, posterior ceratohyal; vhh, ventral hypohyal. Scale bar $=1 \mathrm{~mm}$. Figure 3B and 3D are schematic illustrations of the teeth, thus no scale bar is presented. The cartilaginous hypobranchials are not illustrated in Figure 3E.

lamp-eye clade as supported by morphological studies (Roberts 1970, Parenti 1981, Costa 1996, Ghedotti 2000). Although the position of $F$. simplex is only moderately supported in the analyses, other studies using different molecular data sets indicate that Fluviphylax is not closely related to African lamp-eyes (Pollux et al. 2014; Reznick et al. 2017).

\section{Taxonomic implications}

The present tree topology indicates relationships not compatible with the current classification of the Cyprinodontoidei. Two families, Cyprinodontidae and Poeciliidae, proposed by Parenti (1981) and subsequent authors using morphological characters, are not monophyletic, highlighting the need for a new classification at the family level. In order to avoid too much impact on the current classification, we herein minimize changes in the classification of the Poeciliidae, using family group names already available. The genus Pantanodon, supported as the sister group of all other cyprinodontoids, is placed in its own family, Pantanodontidae Myers 1955, new usage, corresponding to Pantanodontinae of Myers (1955),
Whitehead (1962) and Rosen (1965). Procatopodidae Fowler 1916, new usage, is used for the well supported African lamp-eye clade, being equivalent to Aplocheilichthyinae sensu Parenti (1981), and Fluviphylacidae Roberts 1970, new usage, for the South American genus Fluviphylax, equivalent to Fluviphylacinae sensu Parenti (1981). Poeciliidae Bonaparte 1831 is restricted to the American livebearers (= Poeciliinae sensu Parenti 1981), restoring Poeciliidae as delimited by authors prior to 1981 (e.g. Hubbs 1924).

The genus Pantanodon until recently comprised only two extant species, P. stuhlmanni, from brackish water environments of coastal river drainages in Kenya and Tanzania, and P. madagascariensis from freshwater environments of forested areas in northern Madagascar drainages (e.g. Whitehead 1962, Arnoult 1963). Costa (2012a) reviewed Tertiary cyprinodontoid fossil taxa from central Europe, transferring three species previously placed in Prolebias Sauvage, 1874 to Pantanodon: P. cephalotes (Agassiz 1839) from the upper Oligocene of d'Aix-enProvence, southern France; P. egeranus (Laube 1901) from the Karpatian, lower Miocene of the Cheb basin, 
Czech Republic; P. malzi (Reichenbacher and Gaudant 2003) from the upper Oligocene-lower Miocene of Germany. Subsequently, Gaudant (2013) described a new genus, Paralebias, for those fossil species. However, since those fossil species exhibit synapomorphies used to diagnose Pantanodon (Costa, 2012a) and no unique derived character state was used to diagnose Paralebias by Gaudant (2013), the latter genus is here considered as a synonym of the former. More recently, another fossil species was assigned to Paralebias, P. conquensis Gaudant and Reichenbacher, 2015 from the Miocene of the Tagus Basin, Spain (Gaudant et al. 2015), herein tentatively placed in Pantanodon by possessing claw-shaped hooks on the tip of male pelvic fin, an apomorphic diagnostic feature of Pantanodon. Pantanodon, the only genus of Pantanodontidae here considered as valid, has been diagnosed by several apomorphic conditions: (1) presence of a boomerang-shaped lachrymal (Fig. 2C), (2) extremely reduced nasal (Fig. 2B), (3) dentary and angulo-articular fused in a single structure with coronoid process extending backwards over the quadrate (Fig. 2A), (4) dentary and premaxilla with expanded bone flange (Fig. 2A), (5) tricuspid pharyngeal teeth (Fig. 3B), (6) hypobranchials not ossified (Fig. 3E), (7) epibranchials 1-3 minute or absent (Fig. 3A), (8) second pharyngobranchial tooth plate triangular (Fig. 3A), (9) fifth ceratobranchial and third pharyngobranchial teeth arranged in transverse rows (Fig. 3A, E), (10) fifth ceratobranchial drop-shaped (Fig. 3E), (11) pelvic bone long and narrow (Fig. 2E), and (12) claw-shaped hooks on the tip of outer three or four pelvic-fin rays in males (Parenti 1981, Costa 1998, 2012a). All these characters are herein confirmed in specimens examined (list of specimens examined presented in Supplementary material 2).

\section{Acknowledgments}

We are grateful to F. Milvertz and B. Nagy for donating specimens of $P$. stuhlmanni and providing pictures of $\mathrm{P}$. stuhlmanni, to R. Bayer for donating African lamp-eye specimens and to P. Bartsch, G. Clément, B. Ekrt, W. Fink, Z. Gabsi, Z. Johanson, C. Lamour, J. Maclaine, D. Nelson, M. Parrent, P. Pruvost, M. Richter, J. Snoeks, M. Veran, E. Vreven, and F. Witzmann, for hospitality during visits to their institutions. We are also grateful to J.L. Mattos for help during molecular analyses and to reviwers J. Snoeks and L. Machado for improving the manuscript with corrections and suggestions during the review process. Part of this study was conducted by PHNB and WJEMC during a long-term stay at MRAC; special thanks to J. Snoeks for providing us fine conditions to develop researches in his institution. This study was supported by CNPq (Conselho Nacional de Desenvolvimento Científico e Tecnológico - Ministério de Ciência e Tecnologia; grant 141813/2014-8 to PHNB and 200627/2015-5 to WJEMC); FAPERJ (Fundação de Amparo à Pesquisa do Estado do Rio de Janeiro, grant
E-26/200.381/2016 to PFA) and CAPES (Coordenação de Aperfeiçoamento de Pessoal de Nível Superior, grant 99999.003613/2015-01 to PHNB).

\section{References}

Arnoult J (1963) Un oryziiné (Pisces, Cyprinodontidae) nouveau de l'est de Madagascar. Bulletin du Muséum Nationale de Histoire Naturelle Série 2 (35): 235-237.

Betancur-R R, Broughton RE, Wiley EO, Carpenter K, López JA, Holcroft NI, Arcila D, Sanciangco M, Cureton II JC, Zhang F, Buser T, Campbell MA, Ballesteros JA, Roa-Varon A, Willis S, Borden WC, Rowley T, Reneau PC, Hough DJ, Lu G, Grande T, Arratia G, Ortí G (2013) The tree of life and a new classification of bony fishes. PLOS Currents Tree of Life. Available online at https://doi.org/10.1371/currents.tol.53ba26640df0ccaee75bb165c8c26288.

Chenna R, Sugawara H, Koike T, Lopez R, Gibson TJ, Higgins DG, Thompson JD (2003) Multiple sequence alignment with the Clustal series of programs. Nucleic Acids Research 31: 3497-3500. https:// doi.org/10.1093/nar/gkg500

Costa WJEM (1996) Relationships, monophyly and three new species of the neotropical miniature poeciliid genus Fluviphylax (Cyprinodontiformes: Cyprinodontoidei). Ichthyological Exploration of Freshwaters 7: 111-130.

Costa WJEM (1998) Phylogeny and classification of the Cyprinodontiformes (Euteleostei: Atherinomorpha): a reppraisal. In :Malabarba LR, Reis, RE, Vari RP, Lucena ZMS, Lucena CAS (Eds) Phylogeny and classification of Neotropical Fishes. Edipucrs, Porto Alegre, 537-560.

Costa WJEM (2006) Descriptive morphology and phylogenetic relationships among species of the Neotropical annual killifish genera Nematolebias and Simpsonichthys (Cyprinodontiformes: Aplocheiloidei: Rivulidae). Neotropical Ichthyology 4(1): 1-26. https://doi. org/10.1590/S1679-62252006000100001

Costa WJEM (2012a) Oligocene killifishes (Teleostei: Cyprinodontiformes) from southern France: relationships, taxonomic position, and evidence of internal fertilization. Vertebrate Zoology 62: 371-386.

Costa WJEM (2012b) The caudal skeleton of extant and fossil Cyprinodontiform fishes (Teleostei: Atherinomorpha): comparative morphology and delimitation of phylogenetic characters. Vertebrate Zoology 62: 161-180.

Darriba D, Taboada GL, Doallo R, Posada D (2012) jModelTest 2: more models, new heuristics and parallel computing. Nature Methods 9: 772. https://doi.org/10.1038/nmeth.2109

Felsenstein J (1985) Confidence limits on phylogenies: an approach using the bootstrap. Evolution 39: 783-791. https://doi. org/10.1111/j.1558-5646.1985.tb00420.x

Folmer O, Black M, Hoeh W, Lutz R, Vrijenhoek R (1994) DNA primers for amplification of mitochondrial cytochrome $\mathrm{C}$ oxidase subunit I from diverse metazoan invertebrates. Molecular Marine Biology and Biotechnology 3: 294-299.

Garman S (1895) The cyprinodonts. Memoirs of the Museum of Comparative Zoology 19: 1-179.

Gaudant J (2013) Occurence of poeciliid fishes (Teleostei, Cyprinodontiformes) in the European Oligo-Miocene: the genus Paralebias nov. gen. Neues Jahrbuch für Geologie und Paläontologie-Abhandlungen 267: 215-222. https://doi.org/10.1127/0077-7749/2013/0305 
Gaudant J, Bárron E, Anadón P, Reichenbacher B, Peñalver E (2015) Palaeoenvironmental analysis of the Miocene Arcas del Villar gypsum sequences (Spain), based on palynomorphs and cyprinodontiform fishes. Neues Jahrbuch für Geologie und Paläontologie-Abhandlungen 277: 105-124. https://doi.org/10.1127/njgpa/2015/0503

Ghedotti MJ (2000) Phylogenetic analysis and taxonomy of the poecilioid fishes (Teleostei: Cyprinodontiformes). Zoological Journal of the Linnean Society 130: 1-53. https://doi.org/10.1111/j.1096-3642.2000. tb02194.x

Hrbek T, Seckinger J, Meyer A (2007) A phylogenetic and biogeographic perspective on the evolution of poeciliid fishes. Molecular Phylogenetics and Evolution 43: 986-998. https://doi.org/10.1016/j. ympev.2006.06.009

Hubbs CL (1924) Studies of the fishes of the order Cyprinodontes. Miscellaneous Publications of the Museum of Zoology University of Michigan 13: 1-31.

Li C, Ortí G, Zhang G, Lu G (2007) A practical approach to phylogenomics: The phylogeny of ray-finned fish (Actinopterygii) as a case study. BMC Evolutionary Biology 7: 44. https://doi. org/10.1186/1471-2148-7-44

López JA, Chen WJ, Ortí G (2004) Esociform phylogeny. Copeia 2004: 449-464. https://doi.org/10.1643/CG-03-087R1

Myers GS (1931) The primary groups of oviparous cyprinodont fishes, Order Cyprinodontes (Microcyprini). Stanford University Publications 6: 1-14.

Myers GS (1955) Notes on the classification and names of Cyprinodont fishes. Tropical fish magazine, March, 7.

Palumbi S R, Martin A, Romano S, McMillan WO, Stice L, Grabowski G (1991) The Simple Fool's Guide to PCR, Version 2. University of Hawaii Zoology Department, Honolulu.

Parenti LR (1981) A phylogenetic and biogeographic analysis of cyprinodontiform fishes (Teleostei, Atherinomorpha). Bulletin of the American Museum of Natural History 168: 335-357.

Pohl M, Milvertz FC, Meyer A, Vences M (2015) Multigene phylogeny of cyprinodontiform fishes suggests continental radiations and a rogue position taxon position of Pantanodon. Vertebrate Zoology 65: 37-44.

Pollux BJA, Meredith RW, Springer MS, Garland T, Reznick DN (2014) The evolution of the placenta drives a shift in sexual selection in livebearing fish. Nature 513: 233-236. https://doi.org/10.1038/nature 13451

Regan CT (1911) The osteology and classification of teleostean fishes of the order Microcyprini. Annals and Magazine of Natural History ser 7 (40): 320-327, pls 1-8. https://doi.org/10.1080/00222931108692944

Reznick DN, Furness AI, Meredith RW, Springer MS (2017) The origin and biogeographic diversification of fishes in the family Poeciliidae. PLoS ONE 12(3): e0172546. https://doi.org/10.1371/journal. pone. 0172546

Roberts TR (1970) Description, osteology and relationships of the Amazonian cyprinodont fish Fluviphylax pygmaeus (Myers and Carvalho). Breviora 347: 1-28.

Ronquist F, Teslenko M, Van der Mark P, Ayres DL, Darling A, Höhna S, Larget B, Liu L, Suchard MA, Huelsenbeck JP (2012) MrBayes 3.2: efficient Bayesian phylogenetic inference and model choice across a large model space. Systematic Biology 61: 539-542. https://doi. org/10.1093/sysbio/sys029
Rosen DE (1964) The relationships and taxonomic position of halfbeaks, killifishes, silversides, and their relatives. Bulletin of the American Museum of Natural History 127: 217-168.

Rosen DE (1965) Oryzias madagascariensis Arnoult redescribed and assigned to the East African fish genus Pantanodon (Atheriniformes, Cyprinodontoidei. American Museum Novitates 2240: $1-10$.

Seegers L (1996) The Fishes of the Lake Rukwa Drainage. Annales du Musée Royal de l'Afrique Centrale, Sciences Zoologiques 287: $1-407$.

Tamura K, Stecher G, Peterson D, Filipski A, Kumar S (2013) MEGA6: Molecular Evolutionary Genetics Analysis Version 6.0. Molecular Biology and Evolution 30: 2725-2729. https://oi.org/10.1093/molbev/mst 197

Taylor WR, Van Dyke OC (1985) Revised procedures for staining and clearing small fishes and others vertebrates for bone and cartilage study. Cybium 9: 107-109.

Wainwright PC, Smith WL, Price SA, Tang KL, Sparks JS, Ferry LA, Kuhn KL, Eytan RI, Near TJ (2012) The evolution of pharyngognathy: a phylogenetic and functional appraisal of the pharyngeal jaw key innovation in labroid fishes and beyond. Systematic Biology 61: 1001-1027. https://doi.org/10.1093/sysbio/sys060

Whitehead PJP (1962) The Pantanodontinae, edentulous toothcarps from East Africa. Bulletin of the British Museum of Natural History 9: 105-137. https://doi.org/10.5962/bhl.part.16339

Xia X (2013) Dambe5: a comprehensive software package for data analysis in molecular biology and evolution. Molecular Biology and Evolution 30: 1720-1728. https://doi.org/10.1093/molbev/mst064

Xia XH, Xie Z, Salemi M, Chen L, Wang Y (2003) An index of substitution saturation and its application. Molecular Phylogenetics and Evolution 26: 1-7. https://doi.org/10.1016/S10557903(02)00326-3

Zwickl DJ (2006) Genetic algorithm approaches for the phylogenetic analysis of large biological sequence datasets under the maximum likelihood criterion. PhD dissertation, Austin, Texas: University of Texas.

\section{Supplementary material 1}

\section{List of species, localities and respective Gen- bank accession numbers}

Authors: Pedro Henrique Negreiros de Bragança, Pedro Fasura de Amorim, Wilson José Eduardo Moreira da Costa

Data type: Microsoft Excel Worksheet (.xls) file

Copyright notice: This dataset is made available under the Open Database License (http://opendatacommons. org/licenses/odbl/1.0/). The Open Database License $(\mathrm{ODbL})$ is a license agreement intended to allow users to freely share, modify, and use this Dataset while maintaining this same freedom for others, provided that the original source and author(s) are credited.

Link: https://doi.org/10.3897/zse.94.22173.suppl1 


\section{Supplementary material 2}

\section{Material examined}

Authors: Pedro Henrique Negreiros de Bragança, Pedro Fasura de Amorim, Wilson José Eduardo Moreira da Costa

Data type: Microsoft Word Document (.docx) file

Copyright notice: This dataset is made available under the Open Database License (http://opendatacommons. org/licenses/odbl/1.0/). The Open Database License $(\mathrm{ODbL})$ is a license agreement intended to allow users to freely share, modify, and use this Dataset while maintaining this same freedom for others, provided that the original source and author(s) are credited.

Link: https://doi.org/10.3897/zse.94.22173.suppl2

\section{Supplementary material 3}

\section{Maximum Likelihood (A) and Bayesian In- ference $(B)$ analysis including the $16 \mathrm{~S}$ gene.}

Authors: Pedro Henrique Negreiros de Bragança, Pedro Fasura de Amorim, Wilson José Eduardo Moreira da Costa

Data type: TIF File (.tif) file

Explanation note: Maximum Likelihood (A) and Bayesian Inference (B) analysis including segments of the nuclear genes ENC1, GLYT, MYH6, SH3PX3, RAG1, the mitochondrial genes $16 \mathrm{~S}$ and first and second codon position of the COI. In ML, bootstrap values under 50 are not represented, and posterior probability values under 0.5 are not represented in BI.

Copyright notice: This dataset is made available under the Open Database License (http://opendatacommons. org/licenses/odbl/1.0/). The Open Database License $(\mathrm{ODbL})$ is a license agreement intended to allow users to freely share, modify, and use this Dataset while maintaining this same freedom for others, provided that the original source and author(s) are credited.

Link: https://doi.org/10.3897/zse.94.22173.suppl3

\section{Supplementary material 4}

\section{Substitution models according to JModeltest} 2.1.7

Authors: Pedro Henrique Negreiros de Bragança, Pedro Fasura de Amorim, Wilson José Eduardo Moreira da Costa

Data type: Microsoft Excel Worksheet (.xlsx) file

Copyright notice: This dataset is made available under the Open Database License (http://opendatacommons. org/licenses/odbl/1.0/). The Open Database License $(\mathrm{ODbL})$ is a license agreement intended to allow users to freely share, modify, and use this Dataset while maintaining this same freedom for others, provided that the original source and author(s) are credited. Link: https://doi.org/10.3897/zse.94.22173.suppl4

\section{Supplementary material 5}

\section{Bayesian Inference tree}

Authors: Pedro Henrique Negreiros de Bragança, Pedro Fasura de Amorim, Wilson José Eduardo Moreira da Costa

Data type: TIF File (.tif) file

Explanation note: Bayesian inference tree comprising segments of the nuclear genes ENC1, GLYT, MYH6, SH3PX3, RAG1 and first and second codon position of the mitochondrial gene COI $(5,083 \mathrm{bp})$. Numbers on each node are posterior probablity values; values under 50 are not present in the tree.

Copyright notice: This dataset is made available under the Open Database License (http://opendatacommons.org/licenses/odbl/1.0/). The Open Database License $(\mathrm{ODbL})$ is a license agreement intended to allow users to freely share, modify, and use this Dataset while maintaining this same freedom for others, provided that the original source and author(s) are credited.

Link: https://doi.org/10.3897/zse.94.22173.suppl5 